\title{
CRESCIMENTO CIENTÍFICO EM ÉPOCA DE MUDANÇAS
}

É com muito prazer que a Revista CEFAC - Speech, Language, Hearing Sciences and Education Journal oferece aos leitores, nesse fascículo, um número maior de artigos. Passamos para 25 artigos englobando artigos originais, de revisão e relatos de casos. Mais uma vez, trata-se de material de inequívoca consistência científica e fundamental para mostrar a grande produção dos autores de todo o país e das mais diferentes instituições. É mais uma manifestação de como se transforma, de maneira eficiente, experiência e conhecimentos científicos em produção científica. Nesse contexto, nossa missão é divulgar essa produção disponibilizando o material na íntegra aos leitores, com fácil acesso.

Nos últimos anos a submissão de artigos científicos cresceu muito, mostrando o empenho dos profissionais e cientistas em mostrar os processos pelos quais se trilha o caminho da pesquisa. A cada dia e a cada artigo submetido buscamos verificar inicialmente os critérios adotados pelos autores para uma boa escolha científica. Nossa preocupação volta-se inicialmente para a identificação do problema de pesquisa e o desenvolvimento do método para absorver tal problemática. Lembramos que o caminho nunca deve ser o contrário: "como tem um bom instrumento de pesquisa, procure um problema..." .

Desenvolver um projeto de pesquisa, revisar a literatura a respeito, refinar seus métodos, aprimorar as estratégias, coletar e interpretar os resultados, discutir os achados e finalmente chegar a uma conclusão são etapas desafiadoras mesmo para pesquisadores experientes, porém trata-se de enorme desafio para os iniciantes. Nesse sentido parabenizamos os autores que diariamente submetem seus estudos para publicação na Revista CEFAC. Sabemos que o processo é demorado e custoso, uma vez que a indicação de sugestões e solicitações apontadas pelas avaliações de nossos pareceristas leva a um novo processo de revisão das pesquisas já concluídas. Essas indicações, propiciadas por uma releitura feita por alguém distante do processo, e as consequentes revisões, sem dúvida, resultam em aprimoramento do trabalho.

A ciência muda rapidamente. Os pesquisadores/cientistas, assim como os membros do Corpo Editorial de uma revista, devem estar atentos, ser suficientemente rápidos e disponíveis para seguir as novas tendências e mudanças. Para manter a ciência saudável devemos trabalhar para estimular a inovação. Novas propostas, novas buscas e muita disposição são itens fundamentais no corpo editorial de uma revista científica.

No início de 2009, recebi a enorme incumbência de assumir o cargo de Editora Científica da Revista CEFAC. Foi sem dúvida uma grande honra, pois havia tido a oportunidade de acompanhar a Revista desde sua criação. Foram três anos que passaram rapidamente, nos quais pude ver o enorme crescimento da produção científica encaminhada à Revista CEFAC. Encontramo-nos numa época de grandes mudanças, na qual muito ainda tem que ser buscado. Nesse sentido, chega a hora de nova transição do corpo editorial. É com muito prazer que informo que a partir de janeiro de 2013 , teremos a Dra. Simone Aparecida Capellini à frente da Revista CEFAC como Editora Científica, trazendo muitas propostas enriquecedoras para que a Revista CEFAC possa atingir patamares mais altos no meio científico.

Não deixem de ler o Editorial II, redigido pela Profa. Dra. Simone Aparecida Capellini, especialmente para esse momento de transição em que nos encontramos. Bem vinda ao grupo.

Boa leitura a todos. 